\title{
Canned Questions Using Quranic Verses in English
}

\author{
Dr Lubna Almenoar \\ Assistant Professor of English, Department of Humanities and Social Sciences, College of Science and General \\ Studies, AlFaisal University, Riyadh, Saudi Arabia
}

\begin{abstract}
Questioning as an instructional strategy can aid in student engagement when conducting interactive or communicative type of language teaching and learning. Passive students will inevitably become active when working on the responses to the questioning strategies of teachers. Questioning can also aid the teacher in finding out whether actual learning has taken place through the students' responses.
\end{abstract}

Keywords: Literary Text, Cultural Content, Communicative Language Learning, ESL, Questioning Strategies, Critical Thinking

\section{Introduction}

Questioning is a skill and strategy that teachers must equip themselves with as tools in the field of teaching and learning. This skill is used to help and guide students go deeper into understanding and viewing concepts and facts with clarity. During many classroom activities, the questioning skill comes naturally to a teacher, but there are questions that are more probing and intend to indirectly pave the way to a certain way of thinking. These questions can set the stage for a pre reading prompt, an introduction to a new topic, etc. Extensive research has been done in the questioning strategies areas and it has been proven that working on this area is very beneficial for teachers in upgrading and even stimulating and promoting critical thinking.

Questioning as an instructional strategy can aid in student engagement when conducting interactive or communicative type of language teaching and learning. Passive students will inevitably become active when working on the responses to the questioning strategies of teachers. Questioning can also aid the teacher in finding out whether actual learning has taken place through the students' responses. This being said, teachers should thus not direct questions to only brighter students. In fact, to make sure whether actual learning has taken place, teachers should ask every student regardless of their past achievements in the classroom. All students should have equal opportunity in participation. If a student is unable to answer the question correctly, the teacher's responsibility is to direct the question to same student again but this time having paraphrased the question as a follow-up question. Another questing strategy is to teach students to justify their answers as another type of follow up question. In other words, the follow up for the justification of the responses is "Why?", "How", "In what ways?", "Any example?" These follow up questions will encourage responses that involve a thought process and not guessing.

In an attempt to integrate, incorporate and promote multicultural practices in the language learning classroom, this writer makes a rigorous effort in selecting classroom materials or literary texts depicting a diversified socio-cultural variety to expose her students to different global human societies . For example, this writer has used Japanese short stories, Chinese poems, lyrics of Spanish songs, all of which were translated into the English language. The text chosen for this technique was selected Quranic verses in English.

In this paper, this writer will:

1. Show how using information technology can assist teachers in the quest of using Quranic verses in English as literary texts or reading material. Some useful websites are in APPENDIX 2.

2. Demonstrate how to use Quranic verses in English. More is done in APPENDIX 3.

3. Show selected verses: Verses 1-11, Surah (62) Al-Jumuah(The Friday) (APPENDIX 1)

4. Merge selected verses and technique, Canned Questions.

5. Show and suggest pedagogical approaches whereby teachers are able to see the classroom application of the Quranic Verses in English

6. Reexamine objectives achieved

7. Highlight this paper's contribution to the thematic expression of teaching and learning process of university education as a service to multiculturalism, diversity and globalism.

\section{Current Research On Cultural Competence}

Cakir (2006) discusses the importance of developing culture awareness in the language classroom: In developing cultural awareness in the classroom it is important that we help our students distinguish between the cultural norms, beliefs, or habits of the majority within the speech community and the individual or group 
deviations from some of these norms. Students should be enabled to discuss their native culture with their foreign-speaking friends at the same time that they are provided with a real experiential content.

They can make use of their knowledge of the foreign language. There should also be presented, discussed, or merely alluded to in two parallel streams.

It should also be kept in mind that language teaching, as mentioned above, is a long process in which performance is not absolute and therefore we cannot expect all learners ever to acquire perfect native like behaviour. What we are after is the development of an awareness of sociocultural and sociolinguistic differences that might exist between the students' first language and the target language. Such awareness often help explain to both teachers and students why sometimes there is unintended pragmatic failure and breakdown in communication. If we are aware of it, it might be easier to find the appropriate remedy.

Students will certainly want to use English well and be acknowledged as doing so, but this does not require them to attempt a change in their identity. There is no need to become more American or British in order to use English well. One's morals or dedication to family traditions need not change at all. [1]

(Cakir, 2006)

Center for Open Educational Resources and Language Learning (COERLL) (2012) discusses some cultural issues in the language classroom:

We bring into the classroom our personal cultures, institutional cultures, and even cultures from specific fields of academia, all of which must be somehow integrated into a "class culture" and produce an environment that is conducive to learning.

Some cultural issues that we may encounter in our specific environment are:

- learners' attitudes toward the target language or toward a teacher who may be a non-native speaker.

- parents' expectations from their children and readiness to involve themselves in the educational process, especially when it involves a heritage culture.

- a variety of learning and social interaction styles that by now are ingrained in our adult students.

- different degrees of willingness to accept and support students with language learning disabilities.[2]

(Center for Open Educational Resources and Language Learning (COERLL), 2012)

ESL (2012) discusses ways to promote bicultural awareness in the ESL classroom:

While the ultimate goal of an ESL classroom is to create bilingual students, an additional goal should be to create bicultural students. To do this, teachers should not only practice cultural sensitivity toward their students' native countries, but also encourage students to learn about their new culture. Activities to promote bicultural awareness can include:

- Taking polls of regular students' traditions and beliefs

- Visiting regional attractions such as museums, art exhibits, and historical sites to gain an appreciation of local culture

- Encouraging question and answer sessions about the new culture while comparing it to students' native cultures, such as discussing popular television shows, slang, or other lifestyle characteristics

As students learn to compare their old culture with their new culture, they can gain an appreciation of both without minimizing or denigrating either culture.

The goal of ESL classroom and cultural sensitivity practices should be to impress upon students the value of embracing and understanding their new culture while still celebrating their old cultures. Inviting guest speakers who have successfully integrated into the new culture but who are still active with their native culture can demonstrate that embracing two cultures is possible and can lead to a richer life filled with more treasured cultural experiences than a single culture could produce. Teachers who are sensitive to their students' unique cultures will be able to relate to the students more easily, leading to more successful instruction and more fulfilled students willing to embrace both a new language and a new culture.[3]

\section{Main Objectives Of A Critical Reading Session}

(ESL, 2012)

Saunders et al (1999) revealed four strategies which work and these four strategies are tied with the literary text or reading material used in class. These four points can also be used as a basis or objectives or intended learning outcomes that a teacher would want to achieve at the end of a critical reading session, including the four language skills. Thus, at the end of a critical reading session, a teacher would want students to have exercised and practiced in these areas:

1. Build students' background knowledge.

2. Draw on students' personal experiences.

3. Promote extended discourse through writing and discussion.

4. Assist students in rereading the pivotal portions of the text. [4]

(Saunders et al, 1999) 
5. Use of four language skills

- Reading

- Writing

- Listening

- Speaking

Vogt and Echevarria came up with a technique used to enhance language skills through critical reading. The technique is called "Canned Questions". The highlights of this technique are:

Write questions following Bloom's Taxonomy. The five types of questions should range from lower to higher thinking types response questions. The questions are those based on the literary text or reading material studied in the classroom. The strips of paper with questions are put into a can. Students work in groups to answer the strips of paper questions as the teacher draws them out one by one for each group.

The SIOP Connection to this teaching technique is its higher order level questioning strategy which takes in the form of literal, interpretive or analytical questions. The questions on strips of paper are also put into a can. And students would attempt to answer the questions of gradually increasing cognitive levels in groups.[5]

(Vogt and Echevarria, 2007)

\section{Quranic Literature $\log$ Of A Researcher}

This particular paper marks the third well-thought out plan of this writer for a life-long pursuit of a Quranic Literature Log of her own but perhaps not in the same meaning to that used for a student's Literature Log. This writer will start having a folder of her own called Quranic Literature Log where a list of selected Quranic verses in English by various translators to be used as literary texts or reading material are merged with the technique through various sources for teaching in the Language and Literature classroom. Through this log, a series of new research papers will be written and published.

For this study specifically, the entry which relevantly and tentatively informs is as shown in Table 1Quranic Literature Log:

Table 1-Quranic Literature Log

Quranic Verses: Verses 1-11, Surah (62) Al-Jumuah (The Friday)(APPENDIX 1)

Topic of verses: Not to only think of worldly pursuits

Source of Text:www.Quranix.com

The Qur'an: A Reformist Translation by Dr.EdipYuksel, LaythSaleh al-Shaiban and Dr.Martha Schulte-Nafeh

(Yuksel,al-Shaiban and Nafeh, 2007)

http://www.quranix.com/\#?RTQ $=1 \& \mathrm{~A}=1 \& \mathrm{~L}=$ en $\& \mathrm{NA}=10 \& \mathrm{~S}=94 \& \mathrm{SA}=1$

Technique: Canned Questions

Source of Technique:ptgmedia.pearsoncmg.com/ images/.../samplepages/99ideas.pdf

99 Ideas and Activities for Teaching English Language Learners with the SIOP Model (Vogt and Echevarria, 2007)

Technique: Canned Questions

\section{The Lesson Plan}

Text: Verses 1-11, Surah (62) Al-Jumuah(The Friday) (APPENDIX 1)

Level: Intermediate (undergraduate)

Duration: Two Hours

The following are the main objectives of a Critical Reading session:

Objectives:

1) Build students' background knowledge: Done in bringing focus to the benefit of reflections and discipline because there exists Allah. Students' awareness is raised because there are consequences if we fail to know or ignore our priorities. Academically, students will learn how to different types of questions.

2) Draw on students' personal experience: Done in groups of four when students are asked to work together on answering the questions that the teacher draws out one by one from a can (1) based on the literary text or reading material and can (2) which is answering the questions based on student's experiences related to the literary text or reading material.

3) Promote extended discourse through writing and discussion: Done in discussing and answering questions from can (1) and can (2)answering questions related to each one's experiences as a writing assignment. Done in recording answers of questions from can (1).

4) Assist students in rereading the pivotal portions of the text: Done in discussions when referring to questions in can (2). Students look at each verse (one verse for one question) to attempt the questions. 
5) Use the four skills:

i) Listening: Done in listening to group members answering questions from can (1). Done in groups of four listening to teacher teach each verse at a time before attempting questions in can (1) and can (2).

ii) Speaking: Done in explaining and answering questions from can (1) when working together in groups. Done in oral presentations after recording answers from can (1) in a table.

iii) Reading: Done in reading 11 verses individually and in groups while attempting to answer questions in can (1) and can (2) related to their own experience as a writing assignment.

iv) Writing: Done in writing when recording answers on a table from can(1). Done in recording answers to questions from can (1) in a table. Writing Assignment is answering a question from can(2) as a writing assignment related to experiences.

The teacher can begin by distributing copies of the English translated version of the Quran by Dr Edip Yuksel, specifically verses 1-11, Surah (62) Al-Jumuah (The Friday) (APPENDIX 1), and informing the students where the text is from and also the person who translated the text.

The teacher explains the activities that students will be participating in. That there are two cans of questions. The questions are based on the literary text or reading material that they are about to study. The teacher encourages note taking at this point so that they will be more able to answer the questions in groups. There will be five types of questions:

1. Knowledge

2. Comprehension

3. Application

4. Analysis

5. Synthesis

Teacher adds that on each strip of question, the teacher has written which one of the five types of question that was drawn out from can (1). Each group is to record their answers in the simple large table that the teacher will provide for each group. This table will be used for one selected by each group to come up and present each of his or her own group's answers, with only the table as a visual aid. Each group will attempt to answer at least three of the five types of questions. The table will look like Table 2- Five Types of Question:

Table 2- Five Types of Question

\begin{tabular}{|l|l|l|l|l|l|}
\hline $\begin{array}{l}\text { Type of } \\
\text { Question } \\
\text { Group (1) }\end{array}$ & Knowledge & Comprehension & Application & Analysis & Synthesis \\
\hline Answers & & & & & \\
\hline
\end{tabular}

Then the teacher starts explaining verse by verse. Then the class breaks up into groups and teacher walks over to each group with can (1) questions and the table for each group. The five questions could be as follows:

1. Knowledge: From verse 1, what did God create?

2. Comprehension: From verse 2, why do you think God sent an unlettered messenger to the unlettered people?

3. Application: Explain the simile in verse 5, 'Like the donkey that is carrying a cargo of books.' Who is the donkey and what book is verse 5 referring to?

4. Analysis: In verse 8, what is the sequence of events mentioned about death?

5. Synthesis: In verse 9, why are we reminded to stop what we're doing and hasten to join for prayer on Friday in remembrance of God?

The teacher draws out a strip from can (1) and reads out the question while the group writes the question down. The teacher also mentions the type of question it is. While that group is working on the answer and recording the answer out under the right column in the table, the teacher will do the same to the other groups one by one. The five questions are in rotation and it will be interesting to see how each group attempts to answer the same question. The teacher can allow 30 minutes for this activity.

Then presentation time, each group would choose one to come up and present with the table of answers as a visual aid, talking it through. After all groups have come up to speak, it is can (2) time. The teacher then explains that the next set of questions will be done as writing assignment. Again, the teacher will go around the classroom and each one will have a question strip drawn from can (2). The teacher will also mention what type of question it is. The teacher requests the type of question be included in the writing assignment. The writing assignment is related to the literary text and reading material but the answer is on each one's own experience. 
1. Knowledge: In verse 2, God sent an unlettered man to the unlettered people. In your experience, do you feel it is easier to deal with people like you, meaning your own age, from your own country, from your own neighbourhood? Why do you think so?

2. Comprehension: In verse8, God mentioned death as something that one cannot escape from, it will surely come one day. In your experience, when did you ever attempt to run away from something knowing that it will surely come after you one day?

3. Application: In verse 9, God is saying that we must stop whatever we are doing to go for prayer on Friday, God is saying that it is better for us. Have you been told that something is definitely good for you and yet you do not do it? What were your reasons for not doing it? Do you regret it?

4. Analysis: In verse 5, we are told about two things that don't match-the donkey and books-the donkey will not benefit from having a load of books to carry, the donkey will only hurt its back. Have you ever thought that some subjects you are studying are knowledge that will be of no use later and it is therefore useless to you? Which subjects and why are they useless?

5. Synthesis: In verse 11, we are told of people who are distracted from worshipping God when they are faced with worldly desires and gains, like entertainment and money. Have you been in a situation when you were so tempted into doing something wrong and you couldn't be stopped? Why didn't you stop? What was the most important thing in your mind at that point? Did you regret it? What would have happened if you had stopped?

The teacher goes round the classroom, draws out a question and the student quickly copies the question down, including the type of question. The student begins attempting to answer the question fully as the writing assignment. The teacher continues to go to each student, drawing a question from can (2).

\section{Conclusion}

Teachers are aware that having a classroom with mixed or differing abilities is a challenging task on the teacher's shoulders. A good teacher rarely follows a textbook step by step as many aspects of teaching and learning need to be taken into consideration. With mixed abilities or all with the same level of ability, a teacher must create opportunities for students to demonstrate each one's level of knowledge and to create opportunities to for students to express the way each one thinks. Differentiation practice in classroom strategy and in assessment strategy is always a useful tool for teachers to equip themselves with for more effective teaching and learning.

Where assessment is concerned, evaluation is then called for but still heeding the differentiation approach. The assessments should reflect both social and academic performance. Therefore evaluation of assessment should involve all of the following:

1. Completion of task

2. Ability to understand through listening to teacher and peers

3. Ability to explain or make connections or predict in material and content

4. Ability to demonstrate individuality and creativity

5. Availability and ability to make choices in tasks which consider flexibility for different strengths and needs.

This technique, Canned Questions, text of 11 Quranic verses in English and the suitable activities carried out in the classroom, each plays its own role in a teacher's successful critical reading session. They are an integral part of the whole teaching session. The same set of intended learning outcomes or objectives was achieved at the end of the Quranic Critical Reading session.

\section{References}

[1]. Cakir, I. (2006). Developing Culture Awareness in Foreign Language Teaching. Turkish Online Journal of Distance Education. Retrieved from https://tojde.anadolu.edu.tr/tojde23/pdf/article 12.pdf on June 30th, 2012.

[2]. Center for Open Educational Resources and Language Learning (COERLL) (2012). The Culturally Responsive Classroom.The University of Texas at Austin. Retrieved from http://coerll.utexas.edu/methods/modules/classroom/04/ on June 30th, 2012.

[3]. ESL (2012). ESL Classroom and Cultural Sensitivity. Your Dictionary.Retrieved from http://esl.yourdictionary.com/lessonplans/esl classroom-and-cultural sensitivity.html on June 30th, 2012.

[4]. Saunders, W., O'Brien, G., Lennon, D., \& McLean, J. (1999). Making the transition toEnglish literacy successful: Effective strategies for studying literature with transition students. Educational Practice Reports, Center for Research on Education, Diversity and Excellence, UC Berkeley. Retrieved from http://escholarship.org/uc/item/1574p5t1\#page-4 on June 30th, 2012.

[5]. Vogt, M.E. and Echevarria, J. 99 Ideas and Activities for Teaching English Language Learners with the SIOP Model. Boston, Mass: Pearson Education. 2008. 


\section{Appendix 1}

the discussion of the sixty-second surah, al-jumuah, by dr edip yuksel

In the name of God, the Gracious, the Compassionate

The teacher can explain that the reverence and respect to the Almighty precedes every surah or chapter of the Quran. These words emphasize that the verses that follow are indeed from the Almighty. These words underscore the authenticity of the Quran. The words Gracious and Compassionate are some of attributes of Allah and these words are also two of His ninety-nine names.

1. Glorifying God is everything in the heavens and everything on the earth; the King, the Holy, the Noble, the Wise.

The first reminds us to humble ourselves before Allah. And when we pray, glorify and do any kind of worship towards Allah, we are acknowledging Allah as the Creator of everything in heaven and on earth.

2. He is the One who sent to the Gentiles a messenger from among themselves, to recite to them His signs, to purify them, to teach them the book and the wisdom. Before this, they were clearly astray.

Allah sent to the unlettered people a messenger who was also unlettered (just like the people) to convey and to teach them His messages. Before this, they were leading an impure and a life in error and without guidance.

3. To other generations subsequent to them. He is the Noble, the Wise.

His message spread vastly to people who is told of His message and understands, believes and accepts His message.

4. Such is God's grace, which He bestows upon whoever/whomever He wills. God is Possessor of Infinite Grace.

Allah is willing to grant His limitless and infinite Bounty to whoever is willing to receive it.

5. The example of those who were given the Torah, but then failed to uphold it, is like the donkey that is carrying a cargo of book. Miserable indeed is the example of people who denied God's signs. God does not guide the wicked people.

We are reminded of the people who were given a holy book of Torah but they could not uphold it or carry this responsibility. This is like a donkey, which is an animal that connotes stupidity in the Arabic culture, which is carrying a load of books and could not benefit or make good use of the books. It is miserable to be burdened with something that could not be of any use or benefit, such as the people who reject Allah's message. Allah does not guide those wicked people.

The Arrogance of Racism

6. Say, "O you who are Jewish, if you claim that you are God's chosen, to the exclusion of all other people, then you should long for death if you are truthful!"

This verse addresses those who follow the Jewish faith and who claim to be God's chosen while excluding all other mankind. It is right then that those followers should be longing for death, if what they say is the truth.

7. But they will never long for it, because of what their hands have brought forth. God is fully aware of the wicked.

Those followers of the Jewish faith will never long for death because of what their hands have brought forth. Allah is fully aware of the evildoers.

8. Say, "The death that you are fleeing from, it will come to find you. Then you will be returned to the Knower of all secrets and declarations, then He will inform you of everything you had done."

Allah is saying that the time of death will surely come. Then we will all be brought before Allah who is aware and who knows everything beyond a man's perception or vision or mind. Then Allah will make you understand what wrong you have done or used to do.

The Assembly Prayer

9. O you who acknowledge, if the contact prayer is called to on the day of assembly, then you shall hasten towards the remembrance of God, and cease all selling. This is better for you, if you only knew.

When it is the sound of Call for Congregational Prayers (every Friday), one should put everything aside, leave all dealings of commerce (businesses), and hasten or rush to pray altogether and remember Allah. We have to know and be totally convinced that this would be the best and must receive top most priority than anything else.

10. Then, once the contact prayer is complete, you shall disperse through the land and seek God's provisions, and remember God frequently, so that you may succeed.

When The Friday Congregational Prayers is done and over, you are allowed to disperse and go about seeking your livelihood from Allah's Bounty. But we are reminded to keep remembering Allah frequently and regularly by our five times daily prayers so that we can attain a calm and contented state of mind and being.

11. If they come across any trade, or some entertainment, they rush to it and leave you standing, say, "What God possesses is far better than entertainment or trade. God is the best Provider." 
There are those who are more aware of worldly pursuits and gains and would rush and go, leaving or missing the time of prayers. Allah is saying that what the prayer can offer is much more than all the worldly pursuits and gains. Allah is the best provider so we should turn to him and not anyone else.

\section{APPENDIX 2}

USING INFORMATION TECHNOLOGY

USEFUL WEBSITES:

1. English Index Categorization Alphabetical List of Topics in the Quran:

Retrieved from http://www.quranictopics.com/p3ch1-e.html on June 30th, 2012.

2. The English Translation of The Holy Quran Online:

Retrieved from http://jannah.org/quran/ on June $30^{\text {th }}, 2012$.

3. Islamicity.com-The Holy Quran. The translations are available in multiple languages.

Retrieved from http://www.islamicity.com/mosque/quran/ on June $30^{\text {th }}, 2012$.

4. The way each verse is dealt with by each translator or group of translators is so thorough. After the translation of each verse, a thorough endnote presentation capturing the essence of the surah is laid out. This website is especially useful for researchers and students in the field of translations and comparative literary studies. Retrieved from http://www.quranix.net/\#?RTQ $=1 \& \mathrm{TMG}=1 \& \mathrm{MA}=1 \& \mathrm{RK}=1 \& \mathrm{SH}=1 \& \mathrm{TE}=1 \& \mathrm{~A}=1 \& \mathrm{~L}=$ en $\& \mathrm{NA}=10 \& \mathrm{~S}$ $=1$ on June $30^{\text {th }}, 2012$.

5. A linguistic resource showing the theoretical aspects of linguistics: Arabic grammar, semantics, pragmatics, lexicology, phonology, morphology and syntax of each word in the Quran, the descriptive aspects of linguistics: comparative linguistics, etymology, phonetics and sociolinguistics of words and phrases in the Quran, and the applied linguistics aspects: language and vocabulary development, psycholinguistics and stylistics of the words and phrases in the Quran. At the end of each surah, there is an audio Quran recitation of the surah by the recitor, Saad AlGhamadi. Retrieved from http://corpus.quran.com/wordbyword.jsp on June $30^{\text {th }}, 2012$.

- Teachers can also download Islamic songs on CDs for classroom use. It comes with lyrics of each song, a list of artists and their songs. Retrieved from http://www.islamiclyrics.net/ on June $30^{\text {th }}, 2012$.

\section{APPENDIX 3}

\section{CLASSROOM APPLICATION OF QURANIC VERSES IN ENGLISH}

QURANIC VERSES IN ENGLISH: TEACHING IMAGERY

In the case of Descriptive imagery, an illustrated example is from Abdullah Yusuf Ali's English Translations of the Quran, Verse 29 of Surah(18) Al-Kahf:

Surah (18) Al-Kahf

Verse 29, line 9: That will scald their faces

What type of imagery? Descriptive imagery.

The image gives a vivid description of what the "water like melted brass" can do.

Senses: visual, tactile.

Not only can one imagine feeling the pain of being scalded but one can also picture the disfigurement that the scalding will cause to the faces of the sinners.

In the case of Figurative imagery using the literary device, simile, an illustrated example is from Abdullah Yusuf Ali's English Translations of the Quran, Verse 65 of Surah(37) As-Saffat:

Surah(37) As-Saffat

Verse 65, lines 1-3: $\quad$ The shoots of its fruit-stalks

Are like the heads

Of devils

What type of imagery? Figurative Imagery using the literary device: simile.

The word "like" tells one that a simile is being used to compare the shoots to devils' heads.

Senses: visual.

This image gives a vivid picture in our minds of how evil-looking fruits of this tree in Hell are.

In the case of Figurative imagery, using the literary device, metaphor, an illustrated example is from Abdullah Yusuf Ali's English Translations of the Quran, Verse 50 of Surah(38) Sad:

Surah (38)Sad 
Verse 50, lines 2 and 3: Whose doors will (ever)

Be open for them

What type of imagery? Figurative imagery using a literary device: metaphor.

These doors to the beautiful gardens are forever open to the righteous. Normally, when one thinks of doors, they can either be open or closed. But these doors in Heaven will forever be open. The image metaphorically compares the entrance or passage into Heaven, which we cannot truly visualize, to "doors" in which case Heaven is compared to a gracious house or one's eternal home. The image of open doors depicts Heaven as an abode that feels familiar, hospitable, welcoming.

Senses : visual.

The image suggests a mental picture.

In the case of Figurative imagery using the literary device, symbol, an illustrated example is from Abdullah Yusuf Ali's English Translations of the Quran, Verse of Surah(15) Muhammad:

Surah (47) Muhammad

Verse 15, lines 6-8: $\quad$ Rivers of milk

Of which the taste

Never changes

What type of imagery? Figurative imagery using a literary device: symbol.

Again, unlike the earthly milk which can turn sour without refrigeration, this "milk" in Heaven tastes forever fresh. This "milk" can be found in the form of rivers-- in abundance.

Sense: visual, gustatory, tactile, olfactory.

This image makes one imagine whether this "milk" looks like that consumed on earth; how delicious it must taste, and cool it must feel, and fresh it must smell.

QURANIC VERSES IN ENGLISH: STYLISTICS APPLICATION

An illustrated example of a stylistics analysis of Quranic verses in English by translated by Muhammad Asad is Verses 16-18 of Surah(77) Al-Mursalat:

(16) Did We not destroy [so many of] those [sinners] of olden days? (17)And We shall let them be followed by those of later times : (18) [for] thus do We deal with such as are lost in sin.

Analysis: Verses sixteen to eighteen are put together to form one paragraph. These verses explain the punishment that awaits sinners in the Day of Judgement-destruction. Verse sixteen questions and verses seventeen and eighteen answers verse sixteen. Verse seventeen begins with the conjunction "And" and is in the future tense and verse eighteen begins with the conjunction [for] followed by "thus" and is in the present tense. Verse seventeen implies that suffering in the hereafter is bound to befall the sinners of later times even if God wills to spare them in this world. "We" is used to refer to God in these verses. These verses show the timelessness, universality and unchanging laws of God - for the past, present and future - sinners are destroyed.

An illustrated example of a stylistics analysis of Quranic verses in English by Abdullah Yusuf Ali is Verse 27 of Surah (77) Al-Mursalat:

27. And made therein

Mountains standing firm

Lofty (in stature);

And provided for you

Water sweet (and wholesome)?

Analysis: Verse twenty-seven tells one of Allah's creative activity and hence, His existence when it is evident that mountains-hard and solid, high in altitude - are able to distribute or provide man with pure delicious, sweet water in the form of rivers and springs. The conjunction "and" is used twice in lines one and four. The metaphor is describing the mountains as "standing firm, lofty (in stature)" suggests that these mountains are hard, solid and tall or high in altitude. The word, "wholesome", suggests pure and untouched by man. If the wisdom and power of Allah can do so much before our eyes, we therefore, cannot reject His teaching of a still more wonderful future life after death. Verses twenty-five to twenty-seven are in the past tense. 